\title{
Using an adherent cell culture of the mouse subependymal zone to study the behavior of adult neural stem cells on a single-cell level
}

\author{
Felipe Ortega ${ }^{1,4}$, Marcos R Costa $^{2,4}$, Tatiana Simon-Ebert ${ }^{1}$, Timm Schroeder $^{3}$, Magdalena Götz $^{1,3}$ \& \\ Benedikt Berninger ${ }^{1,3}$
}

\begin{abstract}
${ }^{1}$ Department of Physiological Genomics, Institute of Physiology, Ludwig-Maximilians University Munich, Munich, Germany. ${ }^{2}$ Brain Institute, Universidade Federal do Rio Grande do Norte, Natal, Brazil. ${ }^{3}$ Institute of Stem Cell Research, Helmholtz Zentrum München, Neuherberg, Germany. ${ }^{4}$ These authors contributed equally to this work. Correspondence should be addressed to B.B. (benedikt.berninger@helmholtz-muenchen.de).
\end{abstract}

Published online 3 November 2011; doi:10.1038/nprot.2011.404

\begin{abstract}
A comprehensive understanding of the cell biology of adult neural stem cells (aNSCs) requires direct observation of aNSC division and lineage progression in the absence of niche-dependent signals. Here we describe a culture preparation of the adult mouse subependymal zone (SEZ), which allows for continuous single-cell tracking of aNSC behavior. The protocol involves the isolation $(\sim 3 \mathrm{~h})$ and culture of cells from the adult SEZ at low density in the absence of mitogenic growth factors in chemically defined medium and subsequent live imaging using time-lapse video microscopy (5-7 d); these steps are followed by postimaging immunocytochemistry to identify progeny $(\sim 7 \mathrm{~h})$. This protocol enables the observation of the progression from slow-dividing aNSCs of radial/astroglial identity up to the neuroblast stage, involving asymmetric and symmetric cell divisions of distinct fast-dividing precursors. This culture provides an experimental system for studying instructive or permissive effects of signal molecules on aNSC modes of cell division and lineage progression.
\end{abstract}

\section{INTRODUCTION}

The mouse SEZ harbors adult aNSCs that give rise to neurons of distinct subtype specificity throughout adult life ${ }^{1}$. Population studies indicate that aNSCs are slow-dividing cells that share morphological and molecular hallmarks with radial glia and astrogliaa ${ }^{2-6}$. Furthermore, these aNSCs are thought to generate neurons not directly, but indirectly through fast-dividing precursors of distinct identity: fast-dividing precursors with astroglial characteristics (often referred to as activated astroglia) ${ }^{5}$ and fast-dividing cells devoid of astroglial characteristics, called transit-amplifying precursors (TAPs) ${ }^{7}$. However, the precise lineage progression from aNSCs to neuroblasts has not been observed directly, as singlecell tracking is currently not feasible in vivo. The most frequently used in vitro system for studying aNSCs, the so-called neurosphere assay, uses culturing cells isolated from the SEZ with large amounts of mitogenic growth factors, epidermal growth factor (EGF) and fibroblast growth factor-2 (FGF2), under nonadherent conditions, with the result that free-floating clonal aggregates are formed ${ }^{8-10}$. However, the cell-dense structure of these neurospheres hampers tracking the fate of cells at a single-cell level. Furthermore, the addition of mitogens dramatically alters the behavior of the cells so as to preclude studying the physiological sequence of transitions from aNSCs to neuroblasts ${ }^{7,11}$ (for a critical review of the neurosphere assay, see ref. 12). Here we describe a protocol for culturing aNSCs and other progenitors of the adult SEZ at low density under adherent conditions, which enables the assessment of the behavior of these cells in the absence of a niche environment ${ }^{13}$. Following a short delay after isolation from the adult SEZ, mouse aNSCs and other SEZ progenitors can be subjected to continuous live imaging by time-lapse video microscopy ${ }^{14}$. Within a time period of $5-7 \mathrm{~d}$, it is possible to follow the pattern of cell divisions of aNSCs and other progenitors downstream of the lineage and to directly observe lineage progression to reconstruct lineage trees. By using cultures from transgenic mice, it is possible to assess the cellular identity of cells during live imaging; postimaging immunocytochemistry (ICC) allows for assessing the cellular identity of the progeny generated ${ }^{13}$. As an alternative to live imaging, this culture preparation can also be used for classical clonal analysis ${ }^{15,16}$ after retroviral infection of clonal founder cells at the beginning of the experiment. As this culture system avoids the use of mitogenic growth factors, aNSC and progenitor behavior can be examined in the absence of fate changes elicited by these factors ${ }^{13}$. This is reflected by the high rate of neurogenesis from aNSCs in this system, thus very much resembling the behavior of aNSCs in vivo. Single-cell tracking using time-lapse imaging reveals a very reproducible sequence of lineage progressions that is remarkably consistent with previous population-based in vivo studies ${ }^{1}$.

This culture protocol is a further development of previous adherent culture systems of the adult SEZ. Alvarez-Buylla and $\operatorname{Lim}^{17}$ used an adherent preparation of the adult SEZ, but found it necessary to plate cells on an astroglial feeder layer to obtain proliferating cells. Laywell et al. ${ }^{18}$ cultured cells from the postnatal and adult SEZ under adherent conditions for single-cell tracking, but in the presence of EGF and FGF2, which dramatically alter the mode of cell division and cell-fate decisions. In fact, exposure of adult SEZ cultures to EGF and FGF2, both under adherent and neurosphere conditions, largely favors astrogliogenesis over neurogenesis ${ }^{7,13}$, as has been shown in $v i v o^{7,11}$. With the original aim of identifying the intrinsic neuronal differentiation capacity of aNSCs in vitro ${ }^{19,20}$, we cultured cells from the lateral wall of the lateral ventricle, comprising the lateral part of the adult SEZ in the absence of any extrinsic components (growth factors or other cell types), and we noted that cells continue to proliferate despite the absence of EGF or FGF2 or of an astroglial feeder layer ${ }^{13}$. On the basis of these results, we then assessed the culture's suitability for single-cell tracking in vitro. 
Potential applications of the protocol Given the minimized niche influences under low-density culture conditions, the addition of different factors may allow an in vitro reconstitution of molecular components that define the niche environment in vivo. Thus, this protocol allows for examining cell intrinsic mechanisms underlying lineage progression ${ }^{21,22}$ and studying the instructive, selective or permissive effects of extracellular matrix molecules, growth factors, hormones, neurotransmitters or cocultured cells on the mode of cell division as well as on lineage progression ${ }^{23,24}$. For instance, treatment of the culture with EGF and FGF2 during live imaging not only has revealed massive alterations in cell cycle length, mode of cell division (symmetric versus asymmetric) or cell-fate decision (astrogliogenic versus neurogenic), but also has shown changes in cell adhesive properties and migratory behavior ${ }^{13}$.

Fluorescence-activated cell sorting, using specific cell-surface antigens such as CD133/prominin 1 or the EGF receptor, could be used in combination with transgenic mouse lines; for example, mice carrying a human glial fibrillary acidic protein (hGFAP)-GFP transgene ${ }^{25}$ could be used to sort for specific cell types such as aNSCs (hGFAP-driven GFP and prominin expression $)^{2}$ or activated astroglia (hGFAP-driven GFP and EGF receptor expression) $)^{5}$.

In principle, this protocol could also be used for single-cell tracking of aNSCs from other species including human ${ }^{26-28}$.

High-resolution imaging of these cultures should allow direct observation of unequal segregation of fate determinants or other molecules during asymmetric cell division, provided that the relevant molecules can be fluorescently labeled either through transgenic expression or live antibody staining (in the case of cell-surface molecules) ${ }^{14}$. Another application of this culture preparation includes interference with cell intrinsic mechanisms, such as through lentiviral expression of microRNAs directed against key chromatin remodelers, transcription factors and other fate determinants or forced expression of dominant-negative mutants ${ }^{20}$.

There is strong evidence that the adult SEZ is organized in a mosaic fashion with distinct aNSCs generating different types of neurons, i.e., deep or superficial granule neurons, various types of periglomerular neurons and low numbers of glutamatergic interneurons, depending on their region of origin (i.e., rostral versus caudal, dorsal versus ventral or medial $)^{19,29,30}$. In the present protocol, we describe the isolation and culture of aNSCs and progenitor cells residing in the lateral domain of the SEZ in its entire extension. However, isolating aNSCs from different regions of the SEZ, such as the dorsal domain ${ }^{19,29}$, or the rostral migratory stream ${ }^{30}$ should make it possible to address the question of whether distinct aNSCs give rise to different types of lineage trees (i.e., differing
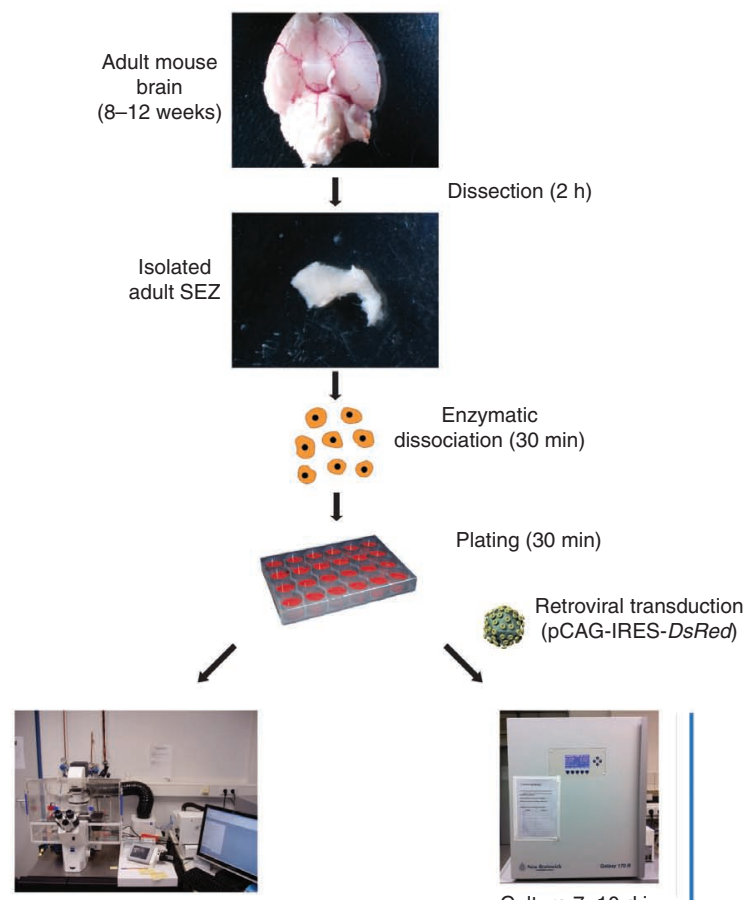

Live imaging

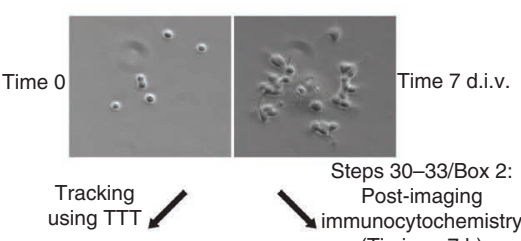

Culture 7-10 d.i.v.
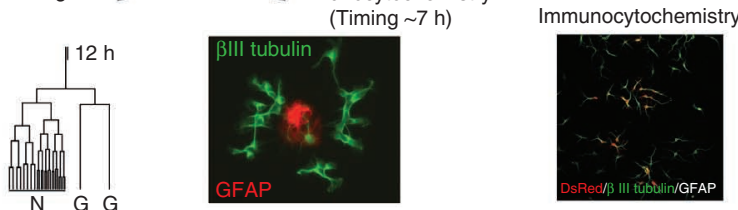

Box 1: Clonal analysis

Figure 1 | Schematic diagram illustrating the major steps of the protocol. Shown are the steps for isolation, primary culture, live imaging and single-cell tracking and clonal analysis of adult subependymal zone neural stem cells.

in the number of amplificatory cell divisions) before generating distinct types of neurons and glia.

One important hallmark of aNSCs is their slow cell cycle ${ }^{31,32}$. Live imaging of SEZ cells in this culture allows for directly assessing the cell cycle length of proliferating cells. Whereas the majority of cells have a rather short cell cycle $(15 \pm 0.25 \mathrm{~h}$ for proliferative divisions and $19 \pm 0.42 \mathrm{~h}$ for terminal divisions), there is a subpopulation of cells that divides after a much longer time window $(>36 \mathrm{~h})^{13}$. These slow-dividing cells are characteristically placed at the top of the lineage and invariably give rise to complex lineage trees that generate numerous neuronal progeny ${ }^{13}$. Importantly, lineage trees initiated by these cells typically show asymmetric cell division that generates both neuronal and astroglial progeny. Thus, a long cell cycle length has predictive power for whether a cell will behave as an aNSC or a fate-restricted progenitor. Moreover, slow-dividing cells are of astroglial identity, as documented by red fluorescence protein (RFP) fluorescence when prepared from transgenic mice driving RFP expression from the human GFAP promoter ${ }^{13}$. Finally, these cells also have a characteristic growth pattern that distinguishes 


\section{BOX 1 | RETROVIRAL-MEDIATED TRANSDUCTION AND CLONAL ANALYSIS TIMING 7-10 D}

This protocol describes the procedure for infecting a low number of actively dividing adult SEZ cells in culture with retroviruses encoding reporter proteins, such as red fluorescent protein (RFP) (pCAG-IRES-DsRed) or green fluorescent protein (pCAG-IRES-GFP). After retroviral-mediated transduction, individual transduced cells will generate progenies expressing the reporter gene, which can be considered of clonal origin (i.e., derived from single progenitor cell when infectivity is sufficiently low) 45,46 . 1. To measure the titer of retrovirus stocks using adult SEZ cells, dilute retroviruses $10,100,1,000,10,000$ times (dilution factor) in B27-supplemented culture medium.

$\triangle$ CRITICAL STEP Typically, retroviral titers are measured using stable cell lines such as HEK293 cells. Because the retroviral genome becomes exclusively incorporated into dividing cells, viral titers will differ among cells with distinct growth kinetics. Therefore, it is recommended to determine the retrovirus titer using adult SEZ cell cultures.

2. Add $1 \mu \mathrm{l}$ of each retroviral dilution to single PDL-coated cover slips containing adult SEZ cells, seeded at a density of 200-300 cells per $\mathrm{mm}^{2}$.

3. After $24 \mathrm{~h}$, fix the cells by the addition of $4 \%$ (wt/vol) PFA (in PBS, pH 7.4) for 5 min at room temperature and then perform ICC for RFP according to the protocol provided in Box 2.

4. Count the number of labeled colonies (usually containing 1-2 cells) per cover slip using a fluorescence microscope and calculate the number of transducing units (TU) using the formula: TU per $\mathrm{ml}=$ number of colonies $(n) \times$ dilution factor (DF) $\times 10^{3}$.

5. Average the results obtained from different dilutions.

6. Prepare retrovirus infection solution by diluting the retrovirus stock in B27-supplemented culture medium in order to obtain no more than 2 TU $\mu \mathrm{L}^{-1}$.

$\triangle$ CRITICAL STEP The retrovirus infection solution should be prepared immediately before transduction in order to prevent retroviral inactivation.

7. Add $10 \mu \mathrm{l}$ of the retrovirus infection solution (i.e., $20 \mathrm{TU}$ ) to individual cover slips containing adult SEZ cells plated $2 \mathrm{~h}$ before at a density of 200-300 cells per $\mathrm{mm}^{2}$ in B27-supplemented culture medium.

I CAUTION Viral handling must be performed in accordance with all relevant safety regulations. The medium containing viral particles must be discarded in accordance with these regulations.

8. Incubate cells for $7-10 \mathrm{~d}$ at $37{ }^{\circ} \mathrm{C}$ with $8-10 \% \mathrm{CO}_{2}$.

9. Fix cells using $4 \%$ (wt/vol) PFA (in PBS, pH 7.4) for $10-15$ min at room temperature $\left(20-25^{\circ} \mathrm{C}\right.$ ).

10. Wash cells with PBS three times for 5 min.

11. Label different cell types within clones by ICC according to the protocol provided in Box 2, using primary antibodies against the reporter protein RFP; neuronal markers, such as $\beta I I I$ tubulin or Doublecortin (DCX); astrocyte markers, such as glial fibrillary acidic protein (GFAP); or oligodendrocyte markers, such as 04 . Use secondary antibodies conjugated to different fluorophores to reveal each of those cell-specific primary antibodies.

$\triangle$ CRITICAL STEP The combination of primary and secondary antibodies should be carefully chosen to avoid cross-reactivity. Use secondary antibodies conjugated with fluorescein isothiocyanate, Cy2 or Alexa Fluor-488 to reveal GFP, and TRITC, Cy3 or Alexa Fluor-546 for RFP because of their natural fluorescence.

12. Use a fluorescence microscope to visualize labeled cells.

13. Count the number of RFP-positive cells within each clone, as well as the number of RFP/DCX or RFP/ $\beta I I I$ tubulin double-positive neurons; RFP/GFAP double-positive astrocytes; and RFP/04 double-positive oligodendrocytes.

$\triangle$ CRITICAL STEP The definition of adult SEZ cells clones relies on the assumption that sibling cells derived from a single transduced progenitor maintain close proximity. Usually, a single SEZ cell clone should be entirely visualized under $\times 100-200$ magnification.

Following the protocol described here, there should be no more than 20 clones per cover slip, so that the average distance between clones should be 5-10 times the radius of an individual clone. If the number of transduced clones is too high, the likelihood of clone overlap will be increased and the clonal analysis will be biased. The reliability of retrovirally based clonal analysis can be ensured by comparing its results to those obtained by video time-lapsed microscopy followed by postimaging ICC.

? TROUBLESHOOTING

14. Classify clones according to their cellular composition in neuronal (all cells are neurons), non-neuronal (none of the labeled cells are neurons) or mixed clones (neurons alongside non-neuronal cells).

them from other progenitors ${ }^{13}$. By using appropriate algorithms $s^{33}$, these features may be used to identify aNSCs in real time for subsequent molecular analyses at a single-cell level ${ }^{34}$.

This assay could be used to study whether the age-dependent decline in aNSC activity is due to changes in the niche environment or is a cell-intrinsic effect. In the latter case, culturing aNSCs under the conditions of this protocol may generate fewer complex lineage trees with asymmetric cell division. In contrast, if the decline in stem cell activity is due to age-dependent changes in the niche environment,
aNSCs obtained from older animals isolated from their niches should not differ substantially from those of younger animals.

Finally, the culture preparation can also be used to study the functional properties of neurons derived from adult SEZ NSCs and progenitor cells after a prolonged time ( $>1$ month) in culture. For instance, we demonstrated that the majority of aNSC-derived neurons give rise to GABAergic neurons, forming functional synapses ${ }^{13,20}$. Conversely, a minority of NSCs isolated from the dorsal aspect of the SEZ give rise to synapse-forming glutamatergic neurons ${ }^{19}$. 


\section{Limitations of the protocol}

Whereas this preparation is ideally suited for analysis at the singlecell level, it cannot be applied to biochemical assays that require large cell numbers. Treatment of the culture with EGF and FGF2 makes it possible to greatly expand the cell numbers, but it involves the above-mentioned alterations.

An inherent biological limitation of the culture concerns the ability to follow long-term self-renewal of aNSCs. Populationbased analysis of self-renewal in vivo suggests that after cell division, aNSCs re-enter the cell cycle after a period of $\sim 2-3$ weeks ${ }^{32}$. The neurosphere assay of aNSC self-renewal again uses treatment with EGF and FGF2 to accelerate aNSC division, but comes at the costs of the above-mentioned alterations of aNSC biology. In the present culture preparation, it is possible to follow the sequence from a single aNSC to the final generation of neuronal and astroglial progeny through a series of symmetric and asymmetric divisions. Notably, asymmetric cell divisions always involve the generation of TAP-producing neuroblasts and one or two (and in rare cases more) cells that maintain radial/astroglial characteristics, such as GFAP expression. These radial/astroglial cells become seemingly quiescent, but they can re-enter cell cycle upon stimulation with EGF and FGF2, thus indicating that they are not permanently postmitotic ${ }^{13}$. Whether these GFAP-positive cells retain full stem cell identity requires further research.

\section{Experimental design}

Overview of the procedure. The protocol presented here allows for single-cell tracking of aNSCs and other SEZ progenitor cells in vitro (Fig. 1), and involves the following steps:

-Dissection of the SEZ (Steps 1-19). The SEZ of adult mice (8-12 weeks) is dissected from the brain and enzymatically dissociated to obtain a single-cell suspension.

- Primary culture of SEZ (Step 20). Cells are placed into poly-Dlysine hydrobromide (PDL)-coated 24-microwell plates (for time-lapse imaging) or PDL-coated cover slips (for clonal analysis) in chemically defined medium. At this or subsequent stages, extrinsic factors can be added to study their effects on cell division and lineage progression.

- Time-lapse imaging (Steps 21-29). Microwell plates containing dissociated SEZ cells are placed on a heated microscope stage kept in an $8 \% \mathrm{CO}_{2}$ atmosphere for imaging during a period of 5-7 d. Images are acquired every 2-5 min to obtain sufficient temporal resolution for single-cell tracking.

- Postimaging ICC (Steps 30-33). After the termination of timelapse imaging, cells are fixed for subsequent ICC to identify the cellular identity of the progeny generated.

- Data analysis (Steps 34-39). By using the Timm's tracking tool (TTT) software ${ }^{24}$, single-cell tracking is performed on each field of view acquired during imaging. Fluorescence micrographs obtained by postimaging ICC are matched to the final image of the time-lapse sequence in order to attribute the cellular identity to the tracked progeny.

- Retroviral transduction for clonal analysis. As an alternative to time-lapse imaging, cells can be transduced 2-4 h after seeding with retroviral vectors for clonal analysis (Box 1). To this end, SEZ cells are typically maintained for 7-10 d before fixation, followed by ICC for the identification of progeny generated within each identified clone.

Control of cellular identity. The identity of the progeny generated at the end of the time-lapse sequence can be ascertained by post-imaging ICC. However, to determine the identity of cells during imaging, other methods need to be used. For instance, in order to assess whether slow-dividing aNSCs have astroglial characteristics, we performed live imaging of SEZ cultures from transgenic mice expressing RFP from the hGFAP promoter ${ }^{35}$. These experiments showed that aNSCs indeed possess astroglial characteristics ${ }^{13}$. Moreover, using these mice we could show that treatment with EGF and FGF2 promotes repeated symmetric division of RFP-positive-and hence astroglial-cells, a behavior that is not observed under control (i.e., mitogen-free) conditions ${ }^{13}$. To identify neuroblasts during live imaging, mice expressing RFP or GFP driven by the doublecortin (DCX) promoter may be used ${ }^{36,37}$. Similarly, it can be useful to determine the cellular identity of other cells within the lineage progression by culturing cells from the adult SEZ of other transgenic animals or knock-in mice. Alternatively, cells may be exposed to fluorescent dye-coupled antibodies against cell-surface antigens during live imaging to identify cells within the lineage $e^{38}$.

\section{MATERIALS}

\section{REAGENTS}

Experimental animals

- C57BL/6J wild-type mice of 8-12 weeks of age. Alternatively, transgenic mice expressing fluorescent reporter proteins under the control of cell type- or stage-specific promoters can be used, such as hGFAP-RFP ${ }^{35}$ ! CAUTION All experiments should be performed in accordance with all relevant governmental and institutional regulations regarding the use of animals for research purposes.

Isolation and culture of adult SEZ cells

- Hanks' balanced salt solution with $\mathrm{CaCl}_{2}$ and $\mathrm{MgCl}_{2}$ (HBSS $10 \times$; Invitrogen, cat. no. 14065-049)

- Hanks' balanced salt solution with $\mathrm{CaCl}_{2}$ and $\mathrm{MgCl}_{2}$ (HBSS $1 \times$; Invitrogen, cat. no. 24020-091)

- Dulbecco's modified Eagle's medium: Nutrient mixture Ham's F-12 without L-glutamine (DMEM/Ham's F-12; PAA, cat. no. E15-012)

- Dulbecco's modified Eagle's medium: DMEM with GLUTAMAX-I with $4.5 \mathrm{~g} \mathrm{l}^{-1} \mathrm{D}$-glucose and sodium pyruvate (Invitrogen, cat. no. 31966021)

- Earle's balanced salt solution without $\mathrm{CaCl}_{2}$ and $\mathrm{MgCl}_{2}$ (EBSS; Invitrogen, cat. no. 14155048)
- Dulbecco's phosphate-buffered saline without $\mathrm{CaCl}_{2}$ and $\mathrm{MgCl}_{2}$ (PBS 10×; Invitrogen, cat. no. 14200-067)

- HEPES buffer solution (1 M; Invitrogen, cat. no. 15630-056)

- Penicillin-streptomycin (Invitrogen, cat. no.15140-122)

- D- (+)-Glucose solution (45\% (wt/vol) in $\mathrm{H}_{2} \mathrm{O}$; Sigma-Aldrich, cat. no. G8769)

- D-(+)-Saccharose (Carl Roth, cat. no. 4621)

- B-27 serum-free supplement (Invitrogen, cat. no. 17504-044) $\Delta$ CRITICAL

Store in appropriate aliquots at $-20^{\circ} \mathrm{C}$. $\boldsymbol{\Delta}$ CRITICAL The exact composition of commercially available B27 is unpublished. We have noticed substantial variability from batch to batch. For practicality, we suggest the use of B27, but in case of marked cell death during imaging or inconsistent results, the use of a defined supplement medium may be indicated. As an alternative to B27-supplemented medium, we have performed single-cell tracking experiments, with identical outcomes to those in which we used B27-supplemented medium, using a completely defined medium ('complete medium') ${ }^{39}$, the exact composition of which is provided below (see REAGENT SETUP). Notably, this medium differs from B27supplemented medium by the absence of the hormones T3 and 
corticosterone. Neither medium formulation differs with regard to retinoic acid precursors. Finally, other B27-based formulations may be used ${ }^{40}$.

- GlutaMAX-I supplement (200 mM; Invitrogen, cat. no. 35050-038)

$\triangle$ CRITICAL Store in appropriate aliquots at $-20^{\circ} \mathrm{C}$.

- Trypsin from bovine pancreas (Sigma-Aldrich, cat. no. T9201)

- Hyaluronidase from bovine testes (Sigma-Aldrich, cat. no. H3884)

- Albumin from bovine serum (BSA; Sigma-Aldrich, cat. no. A2153)

- Hydrochloric acid (1 M; AppliChem, cat. no. A1434)

- Poly-D-lysine hydrobromide (PDL; Sigma-Aldrich, cat. no. P0899)

- Trypan blue stain (Invitrogen, cat. no. 15250-061)

- Ultrapure water (for the preparation of the aqueous solutions, dilution of

buffers and cover slip cleaning and rinsing)

- Paraformaldehyde (PFA; Sigma-Aldrich, cat. no. P6148)

- Antibodies (Table 1)

Supplements for complete medium

- L-Alanine (20 mg; Sigma-Aldrich, cat. no. A-7627)

- Biotin (1 mg; Sigma-Aldrich, cat. no. B-4501)

- L-Carnitine (20 mg; Sigma-Aldrich, cat. no. C-0283)

- Ethanolamine (10 mg; Sigma-Aldrich, cat. no. E-9508)

- D-Galactose (150 mg; Sigma-Aldrich, cat. no. G-0625)

- L-Proline (77.6 mg; Sigma-Aldrich, cat. no. P-0380)

- Putrescine (161 mg; Sigma-Aldrich, cat. no. P-7505)

- Na-Selenite (0.16 mg; Sigma-Aldrich, cat. no. S-5261)

- Vitamin B12 (3.4 mg; Sigma-Aldrich, cat. no. V-2876)

- Zinc sulfate (1.94 mg; Sigma-Aldrich, cat. no. Z-4750)

- Glutathione (10 mg; Sigma-Aldrich, cat. no. G-6013)

- Superoxide dismutase (25 mg; Sigma-Aldrich, cat. no. S-2515)

- Catalase (16 mg; Sigma-Aldrich, cat. no. C-40)

- Linoleic acid (100 mg; Sigma-Aldrich, cat. no. L-1376)

- Linolenic acid (100 mg; Sigma-Aldrich, cat. no. L-2376)

- Progesterone (0.63 mg; Sigma-Aldrich, cat. no. P-8783)

- All-trans retinol (10 mg; Sigma-Aldrich, cat. no. R-7632)

- Retinylacetate (10 mg; Sigma-Aldrich, cat. no. R-7882)

- Tocopherol (100 mg; Sigma-Aldrich, cat. no. T-3251)

- Tocopherolacetate (100 mg; Sigma-Aldrich, cat. no. T-3001)

- Transferrin (100 mg; Sigma-Aldrich, cat. no. T-8158)

- Insulin from bovine pancreas (Sigma-Aldrich, cat. no. I-6634)

$\mathrm{pH}$ adjustment

- $\mathrm{NaOH}, 1 \mathrm{~N}$ (Merck, cat. no. 1091371000)

- HCl, 1N (Merck, cat. no. 1090571000)

Retroviral vectors

- Retroviral vectors expressing reporter proteins (see REAGENT SETUP)

EQUIPMENT

- Microdissection instruments: Dumont no. 5 forceps (Fine Science Tools, cat. no. 11251-20), Dumont no. 5SF forceps (Fine Science Tools, cat. no. 11252-00), $8.5 \mathrm{~cm}$ surgical scissors (Fine Science Tools, cat. no. 14084-08), $8.5 \mathrm{~cm}$ extra-fine spring scissors (Fine Science Tools, cat. no. 15003-08), disposable surgical blades (Schreiber Instruments, cat. no. SM 11-0020-22)! CAUTION All instruments should be sterilized by autoclaving.

- Tissue culture dishes (60 mm; Greiner Bio-One, cat. no. 628160)

- Tissue culture plates (24 well; Orange Scientific, cat. no. 5530305)

- Tissue culture plates (24 well; for time lapse) (Falcon, cat. no. 353047)

- Plastic cover slips (diameter: $13 \mathrm{~mm}$; Sarstedt, cat. no. 83.1840.002)

- Polypropylene conical tubes (15 ml; Greiner Bio-One, cat. no. 188271)

- Polypropylene conical tubes (50 ml; Greiner Bio-One, cat. no. 277261)

- Cotton-plugged glass Pasteur pipettes (230 mm; VWR International,

cat. no. 612-1702, sterilized by autoclaving)

- Cell strainers ( $70 \mu \mathrm{m}$; Falcon, cat. no. 352350$)$

- Syringe filters $(0.2-\mu \mathrm{m}$ pore size; Starstedt, cat. no. 831826001)

- Bottle-top filter systems $(0.22 \mu \mathrm{m}, 500 \mathrm{ml}$; Millipore, cat. no. SCGPT05RE)

- Improved Neubauer hemocytometer (0.1-mm depth, $0.0025 \mathrm{~mm}^{2}$;

Hecht-Assistent, cat. no. 191844272)

- Refrigerated centrifuge and swing-out rotor with adaptors for 15 and $50 \mathrm{ml}$ tubes (Universal 320R; Hettich Lab Technology, cat. no. 1406)

- Humidified cell culture incubator set at $37^{\circ} \mathrm{C}, 8-10 \% \mathrm{CO}_{2}$ (Binder, cat. no. CB210)

- Microcentrifuge (Eppendorf, cat. no. 5452-000-018)

- Magnetic stirrer with hot plate

- $\mathrm{pH}$ meter

- Parafilm (Pechiney)

- Water bath at $37^{\circ} \mathrm{C}$
- Laminar flow hood

- Stereomicroscope (Leica, MZ6)

- Microscope with epifluorescence and appropriate fluorescence filters to match the spectral excitation and emission of at least four different chromophores (Axio Imager, Zeiss)

- Inverted microscope with phase-contrast and epifluorescence equipped with long-distance Plan-Neofluar objectives $(\times 10$ and $\times 20)$, incubation system, scanning stage and AxioVision v4.8 software (Axio Observer, Zeiss; note that other motorized inverted microscopes equipped with temperature and $\mathrm{CO}_{2}$ control systems and acquisition software allowing for the acquisition of multiple $x y z$ positions can be used, such as the IX81 motorized inverted microscope (Olympus) and MetaMorph software for Olympus, BioStation IM-Q (Nikon) or DMI6000 B with adaptive focus control (Leica)).

Incubation system

- Incubator XL S1 with heating unit XL S (Zeiss)

- TempModule S1 (Zeiss)

- $\mathrm{CO}_{2}$-Module S1 (Zeiss)

- Heating insert P S and $\mathrm{CO}_{2}$ cover (Pecon)

- Scanning stage $130 \times 85$ (Zeiss, cat. no. CAN 432031-0000-000)

Tracking system

- Instructions for required hardware, operating system and tracking software requirements, installation and use of TTT and TTTlogfileconverter programs are available at http://www.helmholtz-muenchen.de/isf/ haematopoese/software-download/index.html.

Movie editor

- A free version of ImageJ can be downloaded at http://rsbweb.nih.gov/ij/. REAGENT SETUP

Dissection medium To prepare the dissection medium, add $5 \mathrm{ml}$ of HEPES $1 \mathrm{M}$ (final concentration: $10 \mathrm{mM}$ ) to $500 \mathrm{ml}$ of HBSS $1 \times$. Store the dissection medium at $4{ }^{\circ} \mathrm{C}$ for up to 2 weeks.

Dissociation solution To prepare $5 \mathrm{ml}$ of dissociation solution, dissolve $3.4 \mathrm{mg}$ of trypsin powder and $3.5 \mathrm{mg}$ of hyaluronidase powder in $5 \mathrm{ml}$ of Solution I (see below). $\Delta$ CRITICAL This solution must be prepared shortly before use.

B27-supplemented culture medium To prepare $50 \mathrm{ml}$ of B27-supplemented culture medium, add $1 \mathrm{ml}$ of B27 serum-free supplement, $0.5 \mathrm{ml}$ of penicillinstreptomycin, $0.4 \mathrm{ml}$ of $1 \mathrm{M}$ HEPES buffer solution and GlutaMAX to a final concentration of $2 \mathrm{mM}$; bring up to a final volume of $50 \mathrm{ml}$ with DMEM/F12 (1:1) medium. $\triangle$ CRITICAL Do not use this medium for more than 1 week after preparation.

Complete medium To prepare $400 \mathrm{ml}$ of complete medium, first mix $365 \mathrm{ml}$ of DMEM with GlutaMAX-I (with $4.5 \mathrm{~g} \mathrm{l}^{-1} \mathrm{D}$-glucose and sodium pyruvate) and add each of the supplements as indicated in Table 2. Next, dissolve $1 \mathrm{~g}$ of BSA, $2 \mathrm{mg}$ of transferrin and $1.6 \mathrm{mg}$ of insulin in $30 \mathrm{ml}$ of DMEM with GlutaMAX-I (with $4.5 \mathrm{~g} \mathrm{l}^{-1} \mathrm{D}$-glucose and sodium pyruvate). Mix both solutions, add $4 \mathrm{ml}$ of penicillin-streptomycin, filter-sterilize the solution and store at $4{ }^{\circ} \mathrm{C}$. $\triangle$ CRITICAL Do not use this medium for more than 1 month after preparation.

TABLE 1 | List of primary antibodies for ICC.

\begin{tabular}{|c|c|c|c|}
\hline Antibody & Host & Dilution & Supplier \\
\hline$\beta I I I$ tubulin & Mouse (IgG2b) & $1: 1,000$ & $\begin{array}{l}\text { Sigma-Aldrich, } \\
\text { cat. no. T8660 }\end{array}$ \\
\hline GFAP & Rabbit & $1: 500$ & $\begin{array}{l}\text { DakoCytomation } \\
\text { cat. no. } 20334\end{array}$ \\
\hline GFP & Chicken & $1: 2,000$ & $\begin{array}{l}\text { Aves Labs, } \\
\text { cat. no. GFP-1020 }\end{array}$ \\
\hline DsRed/RFP & Rat & $1: 500$ & $\begin{array}{l}\text { Chromotek, } \\
\text { cat. no. } 5 \mathrm{~F} 8\end{array}$ \\
\hline$D C X$ & Guinea pig & $1: 500$ & $\begin{array}{l}\text { Chemicon, } \\
\text { cat. no. AB2253 }\end{array}$ \\
\hline
\end{tabular}


Solution 1 (HBSS-glucose) To prepare $500 \mathrm{ml}$ of solution 1, mix $50 \mathrm{ml}$ of $10 \times$ HBSS with $6 \mathrm{ml}$ of $45 \%$ (wt/vol) D-(+)-glucose and $7.5 \mathrm{ml}$ of HEPES $1 \mathrm{M}$; bring up to a final volume of $500 \mathrm{ml}$ with pure $\mathrm{H}_{2} \mathrm{O}$. Adjust the $\mathrm{pH}$ to 7.5 with $\mathrm{NaOH}(1 \mathrm{~N})$ and a lab pH meter. Filter-sterilize the solution, prepare appropriate aliquots and store at $-20{ }^{\circ} \mathrm{C}$ for up to 6 months.

Solution 2 (saccharose-HBSS) To prepare $500 \mathrm{ml}$ of solution 2, add $25 \mathrm{ml}$ of $10 \times$ HBSS to D- (+)-saccharose at a final concentration of $0.9 \mathrm{M}(154 \mathrm{~g})$; bring up to a final volume of $500 \mathrm{ml}$ with pure $\mathrm{H}_{2} \mathrm{O}$. Adjust the $\mathrm{pH}$ to 7.5 with $\mathrm{NaOH}(1 \mathrm{~N})$ and a lab $\mathrm{pH}$ meter. Filter-sterilize the solution, prepare appropriate aliquots and store at $-20^{\circ} \mathrm{C}$ for up to 6 months.

Solution 3 (BSA-EBSS-HEPES) To prepare $500 \mathrm{ml}$ of solution 3, add $10 \mathrm{ml}$ of $1 \mathrm{M}$ HEPES to 4\% (wt/vol) BSA dissolved in EBSS; bring up to a final volume of $500 \mathrm{ml}$ with EBSS. Adjust the $\mathrm{pH}$ to 7.5 with $\mathrm{NaOH}(1 \mathrm{~N})$ and a lab $\mathrm{pH}$ meter. Filter-sterilize the solution, prepare appropriate aliquots and store at $-20^{\circ} \mathrm{C}$ for up to 6 months.

Poly-D-lysine hydrobromide stock solution Dissolve $50 \mathrm{mg}$ of PDL powder in pure $\mathrm{H}_{2} \mathrm{O}$ at a concentration of $1 \mathrm{mg} \mathrm{ml}^{-1}$. Filter-sterilize the solution, prepare $1-\mathrm{ml}$ aliquots and store at $-20^{\circ} \mathrm{C}$ for up to 6 months.

Poly-D-lysine hydrobromide working solution Add $1 \mathrm{ml}$ of the PDL stock solution to $50 \mathrm{ml}$ of sterile PBS. Filter-sterilize the solution and store at $4{ }^{\circ} \mathrm{C}$ for up to 2 weeks.

Poly-D-lysine hydrobromide coating of plastic cover slips Add $500 \mu \mathrm{l}$ of PDL working solution to each well of a 24-well tissue culture plate containing plastic cover slips. Incubate the plate for at least $2 \mathrm{~h}$ or overnight at $37^{\circ} \mathrm{C}$. Wash thoroughly three or four times with pure water, and then let the cover slips dry in a laminar airflow hood. Store coated plastic cover slips at $4{ }^{\circ} \mathrm{C}$ for no longer than 1 week. $\Delta$ CRITICAL The best adherence of the plated cells is obtained on fully dried plastic cover slips.

Retroviral vectors For clonal analysis, use VSV-G (Vesicular stomatitis virus-glycoprotein)-pseudotyped retroviruses encoding DsRed located behind an internal ribosomal entry site (IRES). To generate the VSV-Gpseudotyped viral particles, we used a clonal derivative of the retroviral packaging cell line 293GPG (ref. 41). For a detailed protocol for retrovirus preparation and titration, see references 42,43. I CAUTION Production, concentration and handling of VSV-G-pseudotyped retroviruses must be done in accordance with all relevant institutional biosafety guidelines and under S2/BL2 conditions. $\triangle$ CRITICAL Prepare appropriate aliquots of the concentrated viral suspension and store them at $-80^{\circ} \mathrm{C}$ until use. Avoid repeated freeze-thaw cycles.

PFA, 4\% (wt/vol) To prepare $100 \mathrm{ml}$ of $4 \%$ PFA (wt/vol), dilute $4 \mathrm{~g}$ of PFA in $40 \mathrm{ml}$ of $\mathrm{dH}_{2} \mathrm{O}$. Warm up the solution at $70-80{ }^{\circ} \mathrm{C}$ using a hot plate and stir using a magnetic stirrer until the solution turns clear. Allow the solution to $\mathrm{cool}$ at room temperature $\left(20-25^{\circ} \mathrm{C}\right)$ under continued stirring. Add $50 \mathrm{ml}$ of $0.2 \mathrm{M}$ PBS and complete the volume to $100 \mathrm{ml}$ with $\mathrm{dH}_{2} \mathrm{O}$. Adjust the $\mathrm{pH}$ to 7.4 with $\mathrm{HCl}(1 \mathrm{~N})$ and a lab pH meter and aliquot PFA $4 \%(\mathrm{wt} / \mathrm{vol})$ solution in $15-\mathrm{ml}$ conical tubes. The solution can be stored at $4{ }^{\circ} \mathrm{C}$ for up to 1 month. ! CAUTION Paraformaldehyde is a potent fixative and should be handled carefully to avoid any contact with the body. It must be manipulated only inside a fume hood.
TABLE 2 | List of supplements for the preparation of the complete medium.

\begin{tabular}{|c|c|c|}
\hline Supplement & $\begin{array}{l}\text { Stock concentration } \\
\text { and storage }\end{array}$ & $\begin{array}{l}\text { Quantity } \\
\qquad(\mu l)\end{array}$ \\
\hline \multicolumn{3}{|l|}{ Aqueous solution } \\
\hline L-Alanine & $2 \mathrm{mg} \mathrm{ml}^{-1}\left(-20^{\circ} \mathrm{C}\right)$ & 400 \\
\hline Biotin & $0.1 \mathrm{mg} \mathrm{ml}^{-1}\left(-20^{\circ} \mathrm{C}\right)$ & 400 \\
\hline L-Carnitine & $2 \mathrm{mg} \mathrm{ml}^{-1}\left(-20^{\circ} \mathrm{C}\right)$ & 400 \\
\hline Ethanolamine & $1 \mathrm{mg} \mathrm{ml}^{-1}\left(-20^{\circ} \mathrm{C}\right)$ & 400 \\
\hline D-Galactose & $15 \mathrm{mg} \mathrm{ml}^{-1}\left(-20^{\circ} \mathrm{C}\right)$ & 400 \\
\hline L-Proline & $7.76 \mathrm{mg} \mathrm{ml}^{-1}\left(-20^{\circ} \mathrm{C}\right)$ & 400 \\
\hline Putrescine & $16.1 \mathrm{mg} \mathrm{ml}^{-1}\left(-20^{\circ} \mathrm{C}\right)$ & 400 \\
\hline Na-Selenite & $0.016 \mathrm{mg} \mathrm{ml}^{-1}\left(-20^{\circ} \mathrm{C}\right)$ & 400 \\
\hline Vitamin B12 & $0.34 \mathrm{mg} \mathrm{ml}^{-1}\left(-20^{\circ} \mathrm{C}\right)$ & 400 \\
\hline Zinc sulfate & $0.194 \mathrm{mg} \mathrm{ml}^{-1}\left(-20^{\circ} \mathrm{C}\right)$ & 400 \\
\hline Glutathione & $1 \mathrm{mg} \mathrm{ml}^{-1}\left(-20^{\circ} \mathrm{C}\right)$ & 400 \\
\hline Superoxide dismutase & $2.5 \mathrm{mg} \mathrm{ml}^{-1}\left(-20^{\circ} \mathrm{C}\right)$ & 400 \\
\hline Catalase & $16 \mathrm{mg} \mathrm{ml}^{-1}\left(-20^{\circ} \mathrm{C}\right)$ & 64 \\
\hline \multicolumn{3}{|l|}{ Ethanolic solution } \\
\hline Linoleic acid & $100 \mathrm{mg} \mathrm{ml}^{-1}\left(-80^{\circ} \mathrm{C}\right)$ & 4 \\
\hline Linolenic acid & $100 \mathrm{mg} \mathrm{ml}^{-1}\left(-80^{\circ} \mathrm{C}\right)$ & 4 \\
\hline Progesterone & $0.63 \mathrm{mg} \mathrm{ml}^{-1}\left(-80^{\circ} \mathrm{C}\right)$ & 4 \\
\hline All-trans retinol & $10 \mathrm{mg} \mathrm{ml}^{-1}\left(-80^{\circ} \mathrm{C}\right)$ & 4 \\
\hline Retinylacetate & $10 \mathrm{mg} \mathrm{ml}^{-1}\left(-80^{\circ} \mathrm{C}\right)$ & 4 \\
\hline Tocopherol & $100 \mathrm{mg} \mathrm{ml}^{-1}\left(-80^{\circ} \mathrm{C}\right)$ & 4 \\
\hline Tocopherolacetate & $100 \mathrm{mg} \mathrm{ml}^{-1}\left(-80^{\circ} \mathrm{C}\right)$ & 4 \\
\hline
\end{tabular}

\section{PROCEDURE}

\section{Isolation and culture of neural stem cells from the adult mouse SEZ $\bigcirc$ TIMING $\sim 3 \mathbf{h}$}

1| Decapitate 8- to 12-week-old mice.

! CAUTION Handling of experimental animals must be done in accordance with all relevant governmental and institutional regulations regarding the use of animals for research purposes.

$\Delta$ CRITICAL STEP One animal will yield approximately 3-4 × $10^{4}$ cells. Therefore, the number of animals used should be calculated according to the experimental design.

2| Carefully extract the whole brain and place it in a 60-mm Petri dish with ice-cold dissection medium.

3| With the ventral side facing up, transect the brain coronally using a surgical blade at the level of the optic chiasm (Fig. 2a).

4| Turn the brain facing upward and separate both hemispheres using a surgical blade (Fig. 2b). 

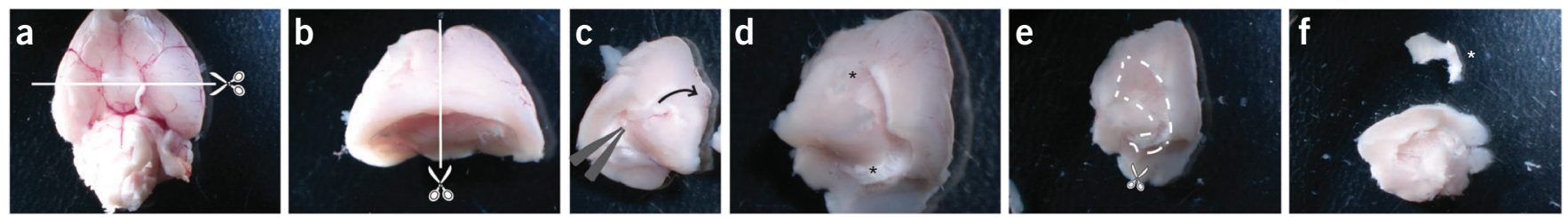

Figure 2 | Preparation of the adult SEZ. (a) Ventral view of an adult mouse brain after extraction. Transect at the level of the optic chiasm using a surgical blade (as shown by white line). (b) Dorsal view of the anterior part of the brain. Separate the two hemispheres using a surgical blade (as shown by white line). (c) Medial view of the left hemisphere. Note the closed ventricle. Use forceps (depicted in gray) to open the ventricle from caudal to rostral; remove the medially located structures by pulling the tissue with the forceps in the direction of the arrow in order to uncover the lateral wall of the lateral ventricle. (d) View of the lateral wall of the lateral ventricle, marked by the two asterisks. (e) Use extra-fine scissors to cut (shown as dotted white line) first the perimeter of the lateral wall of the lateral ventricle and then cut beneath the surface to separate the SEZ from the adjacent striatum. (f) View of the isolated SEZ (asterisk).

5| Open up the ventricle from the caudal side using a forceps (Fig. 2c), uncovering the ventricular face of the lateral wall of the lateral ventricle. The SEZ will be located just beneath the surface formed by a single layer of ependymal cells.

6| By using extra-fine spring scissors, cut the perimeter of the SEZ and then cut off a thin layer beneath the surface, avoiding as much as possible the adjacent striatal tissue (Fig. $\mathbf{2 d - f}$ ). Place it in a 15-ml conical tube containing $10 \mathrm{ml}$ of dissection medium.

$\Delta$ CRITICAL STEP Tissue dissection and manipulation should be performed with maximum care to keep the surface intact and avoid tissue loss.

$\triangle$ CRITICAL STEP If the dissected SEZ tissue contains still portions of the adjacent striatum, trim the tissue with the striatal side facing upward using forceps. The striatal tissue contains myelin, which needs to be removed to avoid excessive debris in the culture.

7| Discard the dissection medium by aspiration with a Pasteur pipette and replace it with $5 \mathrm{ml}$ of filtered and prewarmed $\left(37^{\circ} \mathrm{C}\right)$ dissociation medium. Incubate without shaking at $37^{\circ} \mathrm{C}$ for $15 \mathrm{~min}$.

8| Gently triturate the tissue pieces up and down with a 5-ml sterile disposable pipette ( 10 times) and incubate the solution for another $15 \mathrm{~min}$ at $37^{\circ} \mathrm{C}$.

$\triangle$ CRITICAL STEP At this step, single cells enter into suspension. For the successful isolation of aNSCs and progenitor cells, a complete dissociation of the dissected tissue piece is not required. This is because of the fact that the cells of interest are located just beneath the surface, facing the ventricular side, and thus they enter readily into suspension. Rather, in order to increase the survival of aNSCs, stop the trituration as soon as the medium becomes turbid. The incubation time in dissociation medium should never exceed $30 \mathrm{~min}$ and air bubbles should be avoided during trituration. Complete dissociation of the tissue will only increase cell death and the amount of debris.

9| After trituration, inactivate the trypsin in the dissociation medium by adding $5 \mathrm{ml}$ of ice-cold solution 3 . Gently mix the suspension approximately 10 times with a $10-\mathrm{ml}$ disposable pipette.

10| To remove tissue debris, pass the cell suspension through a $70-\mu \mathrm{m}$ cell strainer into a $50-\mathrm{ml}$ conical tube. Transfer the filtered solution to a fresh $15-\mathrm{ml}$ conical tube.

11| Centrifuge at $200 \mathrm{~g}$ for $5 \min$ at $4^{\circ} \mathrm{C}$.

12| Discard the supernatant and resuspend cells in $10 \mathrm{ml}$ of ice-cold solution 2 using a 10-ml disposable pipette.

13| Centrifuge at $450 \mathrm{~g}$ for $10 \mathrm{~min}$ at $4^{\circ} \mathrm{C}$.

14| Discard the supernatant and resuspend cells in $2 \mathrm{ml}$ of ice-cold solution 3 using a 2-ml disposable pipette.

15| Fill a fresh $15-\mathrm{ml}$ conical tube with $12 \mathrm{ml}$ of ice-cold solution 3.

16| Carefully transfer the cell suspension obtained in Step 13 into the $12 \mathrm{ml}$ of ice-cold solution 3. Do not agitate the cell suspension. 
PROTOCOL

17| Centrifuge at $250 \mathrm{~g}$ for $7 \mathrm{~min}$ at $4^{\circ} \mathrm{C}$.

18| Carefully remove the supernatant and resuspend the cell pellet in prewarmed $\left(37^{\circ} \mathrm{C}\right) \mathrm{B} 27$-supplemented culture medium or complete medium.

19| Count cells in a hemocytometer, using trypan blue to exclude dead cells, as previously described ${ }^{42}$. Usually, we obtain $\sim 30-40,000$ cells per mouse brain.

? TROUBLESHOOTING

20| Seed cells at density of 200-300 cells per $\mathrm{mm}^{2}$ (or the yield of one entire brain per well) directly onto poly-D-lysinetreated 24-well tissue culture plates or onto PDL-coated plastic cover slips for clonal analysis using retroviral-mediated transduction (Box 1). Notably, at the time of plating many of these cells are already doublecortin (DCX)-positive and thus postmitotic ${ }^{13}$. Moreover, a substantial amount of cells undergo cell death during the first $24 \mathrm{~h}$.

? TROUBLESHOOTING

\section{Video time-lapse microscopy $\bigcirc$ TIMING 5-7 d}

21 Switch on the temperature and $\mathrm{CO}_{2}$ controller systems, computer and microscope devices. Run the AxioVision software. Switch on the fluorescence lamp (in experiments in which fluorescence will be analyzed during time-lapse imaging).

22 Set the time-lapse device at $37{ }^{\circ} \mathrm{C}$ and $\mathrm{CO}_{2}$ at $8 \%$ using the AxioVision software (Microscope Menu $\rightarrow$ Incubation). $\triangle$ CRITICAL STEP If no $\mathrm{CO}_{2}$ module is available, it is possible to equilibrate the 24-well tissue culture plate in a regular incubator for $2 \mathrm{~h}$, seal the plate subsequently with Parafilm and then place the plate onto the imaging stage for time-lapse imaging. However, cell survival will not be as good as when using a $\mathrm{CO}_{2}$ atmosphere kept constant at $8 \%$.

? TROUBLESHOOTING

23| Once the $\mathrm{CO}_{2}$ atmosphere and temperature conditions are stable, place the tissue culture plate (from Step 20) on the microscope stage.

$\Delta$ CRITICAL STEP Using a fine-point pen, make a small sign at the bottom of the tissue culture plate before placing it in the microscope. This sign can be used as a reference to set the $x y z$ coordinates (see below).

24| Use a low-magnification objective $(\times 5$ or $\times 10)$ to center the sign made at the bottom of the tissue plate in the field of view of the microscope. In the AxioVision software (Microscope Menu $\rightarrow$ Microscope $\rightarrow X Y Z$ ), set $x y z$ coordinates manually to zero.

$\triangle$ CRITICAL STEP It is extremely important to select a position that can be easily found again whenever the $x y z$ coordinates need to be reset. We recommend taking a snapshot of the zero position in order to be able to exactly reset the correct coordinates.

25| Run the 'smart experiment' application in the AxioVision software.

26 Set the general experiment conditions. We usually use cycles of 2-5 min. Phase-contrast images are captured every cycle and fluorescence images are captured every 90 cycles. Select JPG or TIFF as the image exporting format. AxioVision will save the files together with the corresponding meta_xml files that the TTT logfileconverter (see Step 34) will use to generate acquisition times for the TTT software.

$\Delta$ CRITICAL STEP The higher the frequency with which phase-contrast images are taken, the better the analytical temporal resolution will be. Good temporal resolution is required to ascertain the identity of each cell within a large clone over time, despite some migratory behavior that can easily lead to mixing up the identity of two given cells. However, the lower the frequency of imaging, the more fields of view can be analyzed. Thus, the decision about whether to image at 2- or 5-min cycles involves a tradeoff between these two parameters.

27| Select positions ( $x$ and $y$ coordinates), adjust focus ( $z$ coordinate) and set the exposure time (transmitted light and epifluorescence) for each position. The AxioVision acquisition software will search for the specified $x y z$ coordinates of each field of view in every cycle of the time-lapse experiment.

! CAUTION Light exposure time should be the minimum necessary to acquire images in order to avoid light-induced toxicity. Shutters for both transmitted light and epifluorescence must remain closed between positions and cycles. These recommendations are particularly important for fluorescence images.

$\Delta$ CRITICAL STEP Different regions of the tissue plate have distinct refractive properties. Set the exposure time for the position with the highest phase contrast. 


\section{BOX 2 | POSTIMAGING ICC $\bigcirc$ TIMING $~ 7 \mathrm{H}$}

1. Remove the medium from the plate and wash the cells two times with sterile PBS.

2. Add $400 \mu \mathrm{l}$ of $4 \%$ (wt/vol) PFA in PBS and fix the cells for 10-15 min at room temperature.

3. Wash the cells with PBS three times.

4. Blocking step: Remove the PBS and add $400 \mu \mathrm{l}$ of PBS containing $2 \%$ (wt/vol) BSA and $0.2 \%$ (vol/vol) Triton X-100. Incubate for $1 \mathrm{~h}$ at room temperature.

5. Dilute the primary antibodies (see Table 1 ) in $400 \mu \mathrm{l}$ per well of PBS containing $2 \%$ (wt/vol) BSA and $0.2 \%$ (vol/vol) Triton X-100.

6 . Remove the blocking solution and add the antibody solution. Incubate for $2 \mathrm{~h}$ at room temperature.

7. Remove the antibody solution and wash the cells three times (5-10 min each time) with PBS.

8. Dilute the secondary antibodies in $400 \mu \mathrm{l}$ per well of PBS containing $2 \%$ (wt/vol) BSA and $0.2 \%$ (vol/vol) Triton X-100.

9. Add the secondary antibody solution and incubate for $2 \mathrm{~h}$ at room temperature in the dark.

10. Remove the antibody solution and wash three times (5-10 min each time) with PBS.

11. Keep cells in PBS and proceed to Step 30 of the PROCEDURE.

28| Set the total duration of the experiment (number of cycles). To set the appropriate number of cycles, divide the total time required for the experiment (typically between 5 and $7 \mathrm{~d}$ ) by the cycle length (ranging from 2 to 5 min). However, the experiment can be terminated at any time point before the final cycle.

29| Save settings and run the experiment.

! CAUTION Changes in the focus are typically most prominent within the first $2 \mathrm{~h}$ after the onset of an experiment. Therefore, it is especially important to check the conditions of the focus during this period.

$\triangle$ CRITICAL STEP Small variations in the ambient temperature may affect the chamber temperature, leading to changes in the focus of the images. Check the focal plane regularly and readjust the focus whenever required, overwriting position settings.

? TROUBLESHOOTING

\section{Postimaging ICC $\bigcirc$ TIMING $\sim 7 \mathrm{~h}$}

30| After terminating the imaging experiment, pause the software, remove the plate and process cells for ICC (Box 2).

31| Place the tissue plate back in the microscope stage and search for the sign you used to set the zero in the $x y z$ axis at the beginning of the experiment. Reset the $x y z$ coordinates to zero.

$\triangle$ CRITICAL STEP It is important to reset the $x y z$ coordinates as closely as possible to the original zero point. This will allow you to take new pictures from the same cells imaged before fixation and after ICC.

32| To detect cell-specific antigens revealed by ICC, take pictures of each position using the adequate fluorescence filter set.

33| Save all data from the experiment and proceed to analysis.

\section{Data analysis $\bigcirc$ TIMING $\sim 7 \mathrm{~d}$}

34| Generate log files from images to allow the TTT software to function using the TTTlogfileconverter program.

Instructions for required hardware, operating system and tracking software requirements, and installation and use of TTT and TTTlogfileconverter programs are available at http://www.helmholtz-muenchen.de/isf/haematopoese/software-download/ index.html.

35| Run the TTT software. After opening the TTT software, an overview of all the acquired imaging positions will be displayed, labeled with the number assigned during acquisition. Select one specific position and load the corresponding image for analysis.

36| Select channel 0 (phase-contrast), adjust brightness and contrast.

37| To track cells, select the corresponding displayed options (cell division, apoptosis, lost cell; Supplementary Video 1) for each cell event. These events will be represented in the automatically drawn lineage tree. 
PROTOCOL

38| Match the phase-contrast live images with the immunofluorescence images taken after postimaging ICC to define cell pedigrees.

$\triangle$ CRITICAL STEP Cell identity can also be investigated in live cells by using SEZ cells isolated from transgenic mice expressing reporter proteins under the control of cell type- and stage-specific promoters. Alternatively, to identify cells within the lineage, cells may be exposed to fluorescent dye-coupled antibodies against cell-surface antigens during live imaging $^{38}$.

? TROUBLESHOOTING

39| Export trees and images to an appropriate folder. Exported images can be used to assemble movies using the ImageJ program (http://rsbweb.nih.gov/ij/) or other movie editors.

\section{? TROUBLESHOOTING}

Troubleshooting advice can be found in Table 3.

TABLE 3 | Troubleshooting table.

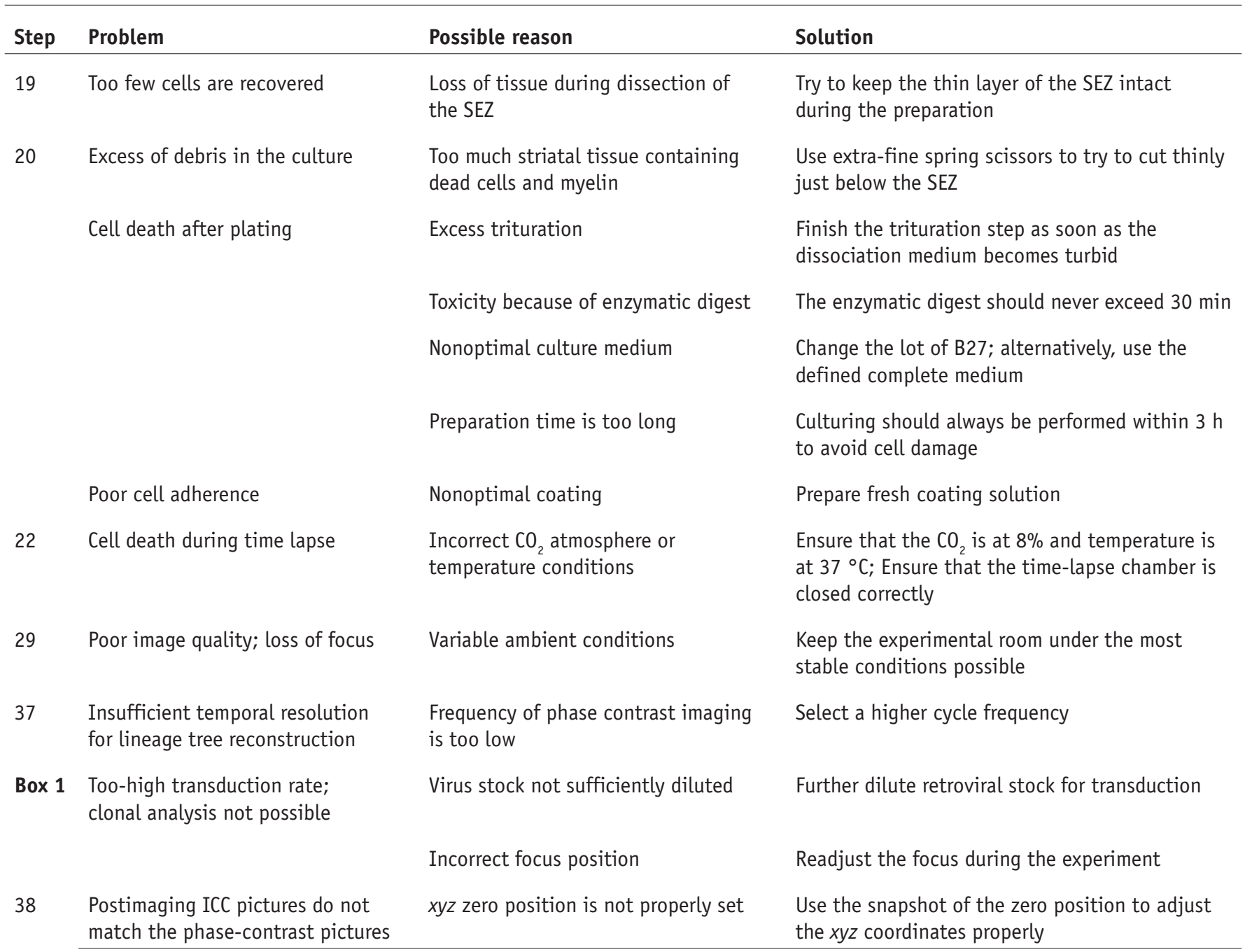

Steps 1-20, Dissection and primary culture of the SEZ: $3 \mathrm{~h}$

Steps 21-29, Time-lapse imaging of the adult SEZ cells: 5-7 d

Steps 30-33, Postimaging ICC: $7 \mathrm{~h}$

Steps 34-39, Data collection and analysis: $7 \mathrm{~d}$ 
Figure 3 | Prototypical lineage trees observed by single-cell tracking of SEZ cultures. Shown are representative lineage trees and their relative frequency of occurrence (percentage shown below each tree). The maximum number of rounds of divisions observed in each class of lineage trees is indicated above each tree. Data are derived from the experiment depicted in Supplementary Figure 1. G, astroglia; N, neuron; X, cell death.
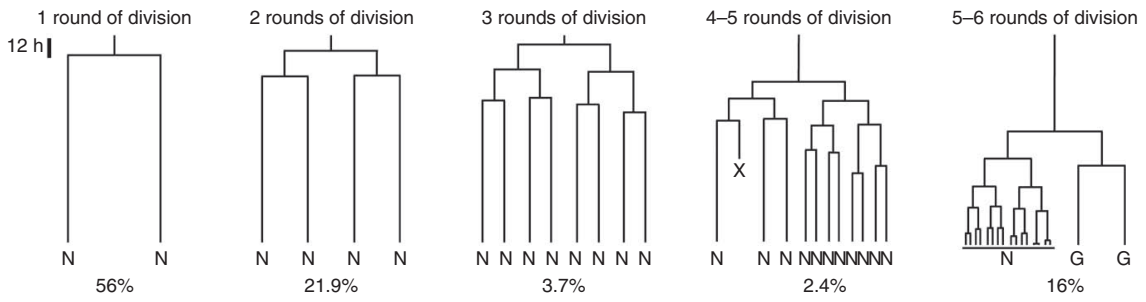

\section{ANTICIPATED RESULTS}

By using this protocol, it is possible to follow the mode of cell division and lineage progression of aNSCs and other SEZ precursors at the single-cell level in vitro. As shown in Figure 3 and Supplementary Figure 1, the vast majority of lineage trees generated under the conditions described here consist of a founder cell generating two neuroblasts by one symmetric terminal cell division ( 46 out of 82 in this experiment). Next frequent are lineage trees characterized by one symmetric proliferative cell division followed by a symmetric terminal division generating four neuroblasts (15 out of 82). More rare are lineage trees characterized by several (three or four) symmetric proliferative cell divisions generating 8-16 neuroblasts (5 out of 82). Besides these purely neurogenic lineage trees, there are typically also lineage trees that contain progeny of astroglial identity besides numerous neuroblasts (13 out of 82). These mixed-lineage trees are characterized by at least one asymmetric cell division along lineage progression and, in many cases, the founder cell of these clones is characterized by a markedly prolonged cell cycle compared with other progenitor cells in these cultures (7 out of 82). These slow-cycling progenitors are operationally identified with aNSCs in the proper sense (see below). In the case of some lineage trees, imaging is terminated before the final progeny is generated and progeny remains negative for neuronal or glial markers (2 out of 82). Finally, under the conditions of the protocol, we rarely observe generation of oligodendroglial progeny. For instance, in the single experiment depicted in Supplementary Figure 1, no oligodendroglial progeny were generated. We cannot exclude the notion that a different medium may be required for optimal survival of oligodendroglial progeny ${ }^{44}$. In most cases, the few oligodendroglial marker-positive cells present in the culture are derived from cells that are already postmitotic when imaging is initiated. Occasionally, under control conditions, a few progenitors can be observed that divide once or twice to generate oligodendroglial progeny (data not shown).

Generation of mixed clones containing BIII tubulin-positive neuroblasts and GFAP-positive astroglia as well as purely neuronal clones can also be observed using classical clonal analysis (Box 1, Fig. 4).

\section{Identification of aNSCs by continuous live imaging}

Adult NSCs can be positively identified on the basis of cumulative evidence. First, aNSCs typically have a much longer cell cycle ( $>36 \mathrm{~h}$ ) than other progenitors ( $<24 \mathrm{~h}$ ) (Figs. 3 and 5 ). However, the total length of time of a cell before completing cell division cannot be determined for the first cell within a continuously imaged lineage tree, as some of this time may have been passed in vivo prior to isolation. Similarly, for a cell at the top of a lineage tree, a short period before cell division does not necessarily indicate that the cell had a short cell cycle. A short cell cycle can only be ascertained for a cell that has been generated in vitro before undergoing cell division. Second, aNSCs typically show substantial growth prior to cell division, in sharp contrast to other progenitor cells ${ }^{13}$ (Fig. 5a,b and Supplementary Video 2). Third, aNSCs give rise to complex lineage trees that comprise both symmetric and asymmetric cell divisions (Figs. $\mathbf{3}$ and $\mathbf{5}$ ). These divisions result in the generation of both neuroblasts as well as one or two (more in rare cases) astroglial progeny. The latter typically enter a quiescent state (Figs. 3 and $\mathbf{5})^{13}$. Finally, aNSCs activate radial glia or astroglia-specific promoters, such as the hGFAP promoter in appropriate mouse lines (data not shown) ${ }^{13}$.

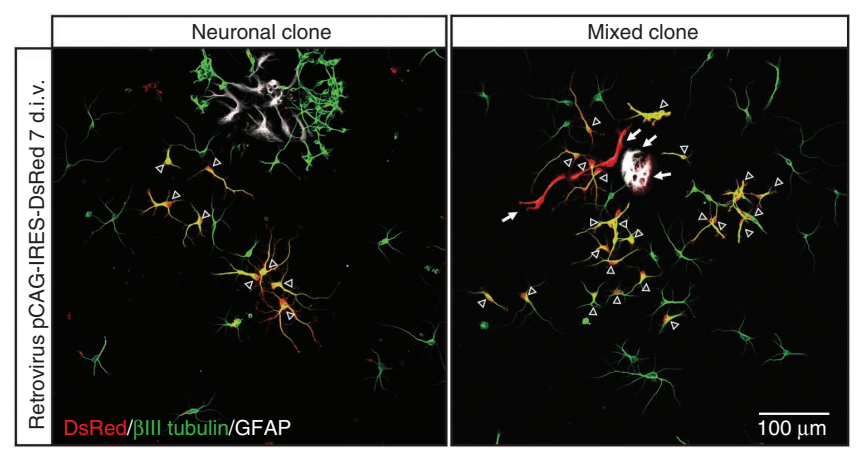

Identification of intermediate precursors within the lineage Generally two types of progenitor cells can be identified: first, fast-dividing cells that have a morphology similar to that of the founder cell (Fig. 5), possess an active hGFAP promoter in hGFAP-RFP transgenic mice and are

Figure 4 | Clonal analysis using retroviral-mediated transduction. Images show examples of two clones derived from single progenitors infected with a retrovirus encoding the reporter protein DsRed (red). After $7 \mathrm{~d}$, cells were fixed and stained for $\beta I I I$ tubulin (green) and GFAP (white). Left, a purely neuronal clone (open arrowheads). Right, a mixed clone containing neurons (open arrowheads) and astroglia (filled arrows). d.i.v., days in vitro. 
Figure 5 | Examples of asymmetric lineage trees. (a,b) Sequences of phase-contrast images depicting the generation of a clone, comprising both neuronal and astroglial progeny. Note that the founder cells underwent massive cell growth between the onset of the experiment and their first division at time points (1-15:40) and (2-12:01), respectively. $(\mathbf{c}, \mathbf{d})$ Corresponding lineage trees as reconstructed from the phasecontrast image sequences shown in $\mathbf{a}, \mathbf{b}$ using TTT. The asterisk indicates the first cell division, the green arrow indicates the cell that gives rise to astroglial progeny and the black arrow indicates the cell that gives rise to the neuronal progeny. Blue arrows indicate transit-amplifying precursors and red arrows indicate the two quiescent astroglial cells. Time is indicated as days-hours: minutes. $\mathrm{G}$, astroglia; $\mathrm{N}$, neuron.

GFAP-immunoreactive (data not shown and ref. 13). These cells are likely to be identical to so-called activated astroglia in vivo ${ }^{5}$. These fast-dividing astroglia typically give rise to neurogenic TAPs and astroglial progeny by asymmetric cell division (Fig. 5a,b). After treatment with EGF and FGF2, it is this population that becomes greatly expanded ${ }^{13}$. The second type is TAPs that do not possess an active hGFAP promoter in hGFAP-RFP transgenic mice and are negative for GFAP immunoreactivity (data not shown and ref. 13). These cells may be identified by the so-called type $C$ cells ${ }^{1}$. These cells seem to be fate-restricted, as they give rise to neuroblasts only (Fig. 5). a
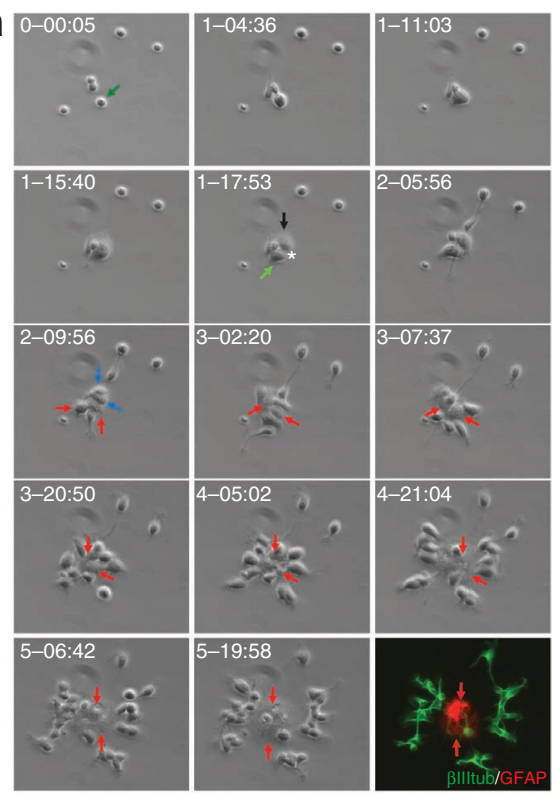

c

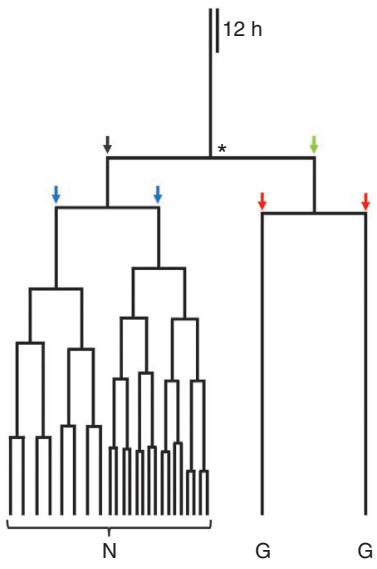

b
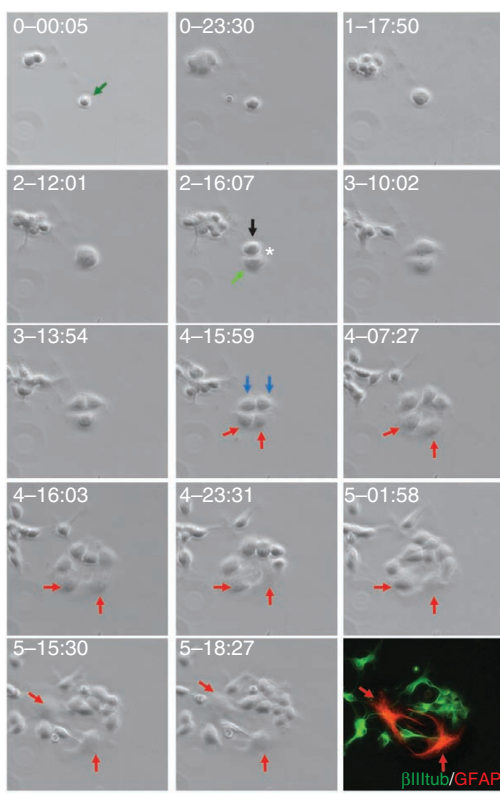

d

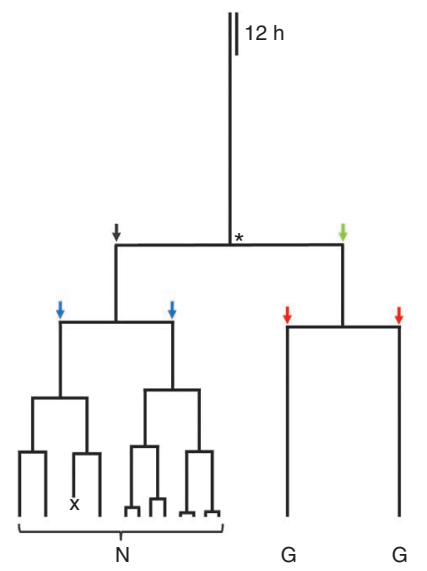

\section{Identification of neuroblasts}

Neuroblasts appear typically at the end of the lineage tree and rarely divide under the conditions of the protocol. A striking feature of the transitions between DCX-negative TAPs and DCX-positive neuroblasts is the fact that neuroblasts start to show enhanced migratory behavior and typically also extend neurites (Supplementary Video 2$)^{13}$.

If they are allowed to grow for a prolonged time period (3-4 weeks), the majority of neuroblasts differentiate into GABAergic neurons ${ }^{13}$, which is consistent with the prevalent expression of Dlx transcription factors ${ }^{20}$. However, if the preparation also contains the dorsal aspect of the SEZ, a small population of cells transiently express Tbr2, a transcription factor of the glutamatergic lineage, and indeed $2-3 \%$ of the entire neuronal progeny acquires a glutamatergic fate ${ }^{19}$.

Note: Supplementary information is available via the HTML version of this article.

ACKNOWLEDGMENTS This work was supported by grants from the Deutsche Forschungsgemeinschaft to B.B. and M.G. (BE 4182/2-2 and G0 640/9-2) and to T.S. (SCHR 1142/1-2), and from the Bundesministerium für Bildung und Forschung (NewNeurons) and the Bavarian State Ministry of Sciences, Research and the Arts (ForNeuroCell) to B.B. and M.G.

AUTHOR CONTRIBUTIONS F.0. and M.R.C. contributed to protocol design, experimental analysis of the culture preparation by single-cell tracking, postimaging ICC and clonal analysis, and the preparation of the manuscript;
T.S.-E. contributed to the culture preparation; T.S. contributed to single-cell tracking by time-lapse video microscopy; M.G. contributed to protocol design and preparation of the manuscript; B.B. developed the culture preparation and contributed to protocol design, experimental analysis and preparation of the manuscript.

COMPETING FINANCIAL INTERESTS The authors declare no competing financial interests.

Published online at http://www.natureprotocols.com/.

Reprints and permissions information is available online at http://www.nature. com/reprints/index.html. 
1. Kriegstein, A. \& Alvarez-Buylla, A. The glial nature of embryonic and adult neural stem cells. Annu. Rev. Neurosci. 32, 149-184 (2009).

2. Beckervordersandforth, R. et al. In vivo fate mapping and expression analysis reveals molecular hallmarks of prospectively isolated adult neural stem cells. Cell Stem Cell 7, 744-758 (2010).

3. Doetsch, F., Caille, I., Lim, D.A., Garcia-Verdugo, J.M. \& Alvarez-Buylla, A. Subventricular zone astrocytes are neural stem cells in the adult mammalian brain. Cell 97, 703-716 (1999).

4. Doetsch, F., Garcia-Verdugo, J.M. \& Alvarez-Buylla, A. Regeneration of a germinal layer in the adult mammalian brain. Proc. Natl. Acad. Sci. USA 96, 11619-11624 (1999).

5. Pastrana, E., Cheng, L.C. \& Doetsch, F. Simultaneous prospective purification of adult subventricular zone neural stem cells and their progeny. Proc. Natl. Acad. Sci. USA 106, 6387-6392 (2009).

6. Mirzadeh, Z., Merkle, F.T., Soriano-Navarro, M., Garcia-Verdugo, J.M. \& Alvarez-Buylla, A. Neural stem cells confer unique pinwheel architecture to the ventricular surface in neurogenic regions of the adult brain. Cell Stem Cell 3, 265-278 (2008).

7. Doetsch, F., Petreanu, L., Caille, I., Garcia-Verdugo, J.M. \& Alvarez-Buylla, A. EGF converts transit-amplifying neurogenic precursors in the adult brain into multipotent stem cells. Neuron 36, 1021-1034 (2002).

8. Reynolds, B.A. \& Weiss, S. Generation of neurons and astrocytes from isolated cells of the adult mammalian central nervous system. Science 255, 1707-1710 (1992).

9. Reynolds, B.A. \& Rietze, R.L. Neural stem cells and neurospheresre-evaluating the relationship. Nat. Methods 2, 333-336 (2005).

10. Rietze, R.L. \& Reynolds, B.A. Neural stem cell isolation and characterization. Methods Enzymol. 419, 3-23 (2006).

11. Kuhn, H.G., Winkler, J., Kempermann, G., Thal, L.J. \& Gage, F.H. Epidermal growth factor and fibroblast growth factor-2 have different effects on neural progenitors in the adult rat brain. J. Neurosci. 17, 5820-5829 (1997).

12. Pastrana, E., Silva-Vargas, V. \& Doetsch, F. Eyes wide open: a critical review of sphere-formation as an assay for stem cells. Cell Stem Cell $\mathbf{8}$, 486-498 (2011).

13. Costa, M.R. et al. Continuous live imaging of adult neural stem cell division and lineage progression in vitro. Development 138, 1057-1068 (2011).

14. Schroeder, T. Long-term single-cell imaging of mammalian stem cells. Nat. Methods 8, S30-S35 (2011).

15. Price, J., Turner, D. \& Cepko, C. Lineage analysis in the vertebrate nervous system by retrovirus-mediated gene transfer. Proc. Natl. Acad. Sci. USA 84, 156-160 (1987).

16. Williams, B.P., Read, J. \& Price, J. The generation of neurons and oligodendrocytes from a common precursor cell. Neuron 7, 685-693 (1991).

17. Lim, D.A. \& Alvarez-Buylla, A. Interaction between astrocytes and adult subventricular zone precursors stimulates neurogenesis. Proc. Natl. Acad. Sci. USA 96, 7526-7531 (1999).

18. Laywell, E.D., Rakic, P., Kukekov, V.G., Holland, E.C. \& Steindler, D.A. Identification of a multipotent astrocytic stem cell in the immature and adult mouse brain. Proc. Natl. Acad. Sci. USA 97, 13883-13888 (2000).

19. Brill, M.S. et al. Adult generation of glutamatergic olfactory bulb interneurons. Nat. Neurosci. 12, 1524-1533 (2009).

20. Brill, M.S. et al. A dlx2- and pax6-dependent transcriptional code for periglomerular neuron specification in the adult olfactory bulb. J. Neurosci. 28, 6439-6452 (2008).

21. Qian, X., Goderie, S.K., Shen, Q., Stern, J.H. \& Temple, S. Intrinsic programs of patterned cell lineages in isolated vertebrate CNS ventricular zone cells. Development 125, 3143-3152 (1998).

22. Shen, Q. et al. The timing of cortical neurogenesis is encoded within lineages of individual progenitor cells. Nat. Neurosci. 9, 743-751 (2006).

23. Ravin, R. et al. Potency and fate specification in CNS stem cell populations in vitro. Cell Stem Cell 3, 670-680 (2008).
24. Rieger, M.A., Hoppe, P.S., Smejkal, B.M., Eitelhuber, A.C. \& Schroeder, T. Hematopoietic cytokines can instruct lineage choice. Science 325, 217-218 (2009).

25. Nolte, C. et al. GFAP promoter-controlled EGFP-expressing transgenic mice: a tool to visualize astrocytes and astrogliosis in living brain tissue. Glia 33, 72-86 (2001).

26. Westerlund, U. et al. Endoscopically harvested stem cells: a putative method in future autotransplantation. Neurosurgery 57, 779-784; discussion 779-784 (2005).

27. Moe, M.C. et al. Multipotent progenitor cells from the adult human brain: neurophysiological differentiation to mature neurons. Brain 128, 2189-2199 (2005).

28. Sanai, N. et al. Unique astrocyte ribbon in adult human brain contains neural stem cells but lacks chain migration. Nature 427, 740-744 (2004).

29. Merkle, F.T., Mirzadeh, Z. \& Alvarez-Buylla, A. Mosaic organization of neural stem cells in the adult brain. Science 317, 381-384 (2007).

30. Hack, M.A. et al. Neuronal fate determinants of adult olfactory bulb neurogenesis. Nat. Neurosci. 8, 865-872 (2005).

31. Morshead, C.M. et al. Neural stem cells in the adult mammalian forebrain: a relatively quiescent subpopulation of subependymal cells. Neuron 13 1071-1082 (1994).

32. Zheng, W., Nowakowski, R.S. \& Vaccarino, F.M. Fibroblast growth factor 2 is required for maintaining the neural stem cell pool in the mouse brain subventricular zone. Dev. Neurosci. 26, 181-196 (2004).

33. Cohen, A.R., Gomes, F.L., Roysam, B. \& Cayouette, M. Computational prediction of neural progenitor cell fates. Nat. Methods 7, 213-218 (2010).

34. Tang, F., Lao, K. \& Surani, M.A. Development and applications of single-cell transcriptome analysis. Nat. Methods 8, S6-S11 (2011).

35. Hirrlinger, P.G. et al. Expression of reef coral fluorescent proteins in the central nervous system of transgenic mice. Mol. Cell Neurosci. 30, 291-303 (2005).

36. Couillard-Despres, S. et al. Doublecortin expression levels in adult brain reflect neurogenesis. Eur. J. Neurosci. 21, 1-14 (2005).

37. Couillard-Despres, S. et al. Targeted transgene expression in neuronal precursors: watching young neurons in the old brain. Eur. J. Neurosci. 24, 1535-1545 (2006).

38. Eilken, H. et al. Continuous long-term detection of live cell surface markers by 'in culture' antibody staining. Protocol Exchange (2011)doi:10.1038/protex.2011.205.

39. Bibel, M., Richter, J., Lacroix, E. \& Barde, Y.A. Generation of a defined and uniform population of CNS progenitors and neurons from mouse embryonic stem cells. Nat. Protoc. 2, 1034-1043 (2007).

40. Chen, Y. et al. NS21: re-defined and modified supplement B27 for neuronal cultures. J. Neurosci. Methods 171, 239-247 (2008).

41. Ory, D.S., Neugeboren, B.A. \& Mulligan, R.C. A stable human-derived packaging cell line for production of high titer retrovirus/vesicular stomatitis virus G pseudotypes. Proc. Natl. Acad. Sci. USA 93, 11400-11406 (1996).

42. Heinrich, C. et al. Generation of subtype-specific neurons from postnatal astroglia of the mouse cerebral cortex. Nat. Protoc. 6, 214-228 (2011).

43. Tashiro, A., Zhao, C. \& Gage, F.H. Retrovirus-mediated single-cell gene knockout technique in adult newborn neurons in vivo. Nat. Protoc. 1, 3049-3055 (2006).

44. Billon, N., Jolicoeur, C. \& Raff, M. Generation and characterization of oligodendrocytes from lineage-selectable embryonic stem cells in vitro. Methods Mol. Biol. 330, 15-32 (2006).

45. Costa, M.R., Bucholz, 0., Schroeder, T. \& Gotz, M. Late origin of glia-restricted progenitors in the developing mouse cerebral cortex. Cereb. Cortex 19 (Suppl 1): i135-i143 (2009).

46. Costa, M.R., Wen, G., Lepier, A., Schroeder, T. \& Gotz, M. Par-complex proteins promote proliferative progenitor divisions in the developing mouse cerebral cortex. Development 135, 11-22 (2008). 